\title{
17. Missing the Revolution! Negotiating disclosure on the pre-Macassans (Bayini) in North-East Arnhem Land
}

\author{
Ian S. Mclntosh
}

By their own admission, members of Charles Mountford's 1948 AmericanAustralian Scientific Expedition to Arnhem Land were motivated by a search for the primitive. It is no surprise, then, that the published records show a singular lack of awareness of the sorts of debate raging within Aboriginal circles at that time. For example, so-called missionised Yolngu (as the Aboriginal people of North-East Arnhem Land are known) were engaged in a major discussion about whether Christianity was an expression of the Dreaming and thus culturally mandated or whether God gave Yolngu the Dreaming as some missionaries insisted.

While the Expedition's point of entry into Aboriginal Australia was through the Christian missions, their focus was salvage anthropology, so it is not clear whether Expedition leader, Charles Mountford, was aware of or interested in this discourse taking place at the highest levels in Yolngu society.

In this chapter, I examine what was lost and what was gained by taking such a tack and not addressing the very real issues at play in Yolngu lives. To highlight this disconnect, I examine Yolngu disclosure relating to ethnographic material 'hunted and gathered' by Expedition members in North-East Arnhem Land pertaining to a curious, then-unidentified (and supposed) group of Asian seafarers known as the Bayini (or Baiini): the pre-Macassans. I then review the changing nature of this disclosure over time for the light it throws on the changing nature of relations between Yolngu and Balanda (non-Aborigines) - a subject that was not considered an Expedition research priority.

In the literature of North-East Arnhem Land, the identity of pre-Macassans as a historical phenomenon has always been something of a conundrum. ${ }^{1}$ In Yolngu circles, while the mystery was also very real, the Bayini occupied centre stage in Yolngu cosmology. All things within the Yolngu realm can be explained by reference to the Dreaming, but to which deity did the stories of these foreign

1 McIntosh, I. S. 1995, 'Who are the Bayini?', The Beagle: Records of the Museums and Art Galleries of the Northern Territory, vol. 12, pp. 193-208. 
visitors belong? Despite exhaustive anthropological research in North-East Arnhem Land, there was no reference to any overarching Dreaming figure or deity that spoke to the existence of non-Aborigines in the Yolngu world. Information regarding a 'Dreaming Macassan' was concealed by Yolngu for reasons that will become clear throughout this paper.

All visitors to Arnhem Land since the 'beginning of time'-including random and unplanned Indonesian visitors, Portuguese and Dutch explorers, trepanging Macassans, Japanese pearlers and Europeans (of all descriptions)were explainable, in part, through the prism of Bayini narratives and the 'Dreaming Macassan'. But these narratives-known in the literature only in fragments through the extended captions associated with Yolngu drawings collected by Charles Mountford-provided only a glimpse into what is a very complex subject. And yet, even with the little information that was openly shared by Yolngu, it was apparent that the Bayini narratives were concernedat a fundamental level — with Yolngu lives and Yolngu futures in a world that was increasingly being dominated by outsiders. Given the increased exposure of Yolngu to outsiders - including missionaries, anthropologists, and military personnel (during World War II) - a decision was made by Yolngu elders to send the Bayini narratives (and the 'Dreaming Macassan') further 'inside' into the non-accessible realm of the sacred and to restrict access to interpretations that might be construed as privileging the place of whites or other outsiders on Yolngu land. After all, the ancestors of the Yolngu, the Bayini, were white and all-powerful! How easy would it have been for the present-day non-Aborigines to assert some mythical connection to the land and further usurp Yolngu authority - as certainly happened in other parts of Australia in the colonial era when non-Aborigines perpetuated the notion that they, as whites, were the Aboriginal deceased come back to life to reclaim their rightful heritage. So this process of reinterpretation of a public story as a 'hidden transcript' was a priority in the mission setting where power lay not in traditional hands but in those of the select few missionaries and their appointed Aboriginal interlocutors.

For the purposes of public or 'outside' discussion with their interrogators, Yolngu would, post 1948, describe the Bayini as the predecessors of Macassans. They were indeed a historical group, Yolngu said, but they also possessed extraordinary supernatural powers. And yet their provenance and activities were shrouded in secrecy.

I will argue that an understanding of the changes taking place in Yolngu lives is understandable only through the prism of the Bayini and that the significance of the Bayini paintings and myths is not possible without reference to the aforementioned 'hidden transcript' or the broader struggle of Yolngu for their rights to the land and sea, and their right to practise the religion of their choice in a manner of their choosing. By not engaging with mission Yolngu on their 
efforts to integrate the traditional (including Islamic-inspired beliefs) ${ }^{2}$ and the modern, and ending the great disparity in wealth between black and white, the Expedition missed a chance to document what was a remarkably dynamic period of Yolngu-directed change in the mid twentieth century. It might be argued that the team members were not in any one location long enough to elicit detailed information on the Bayini, but I would counter with the assertion that if Yolngu Christianity had been taken seriously, and the people treated with the respect and dignity that were owed them as landowners, the mystery of the Bayini would not have been a mystery at all. There would not have been any reason to conceal these narratives from the Expedition members or those researchers who came in their wake.

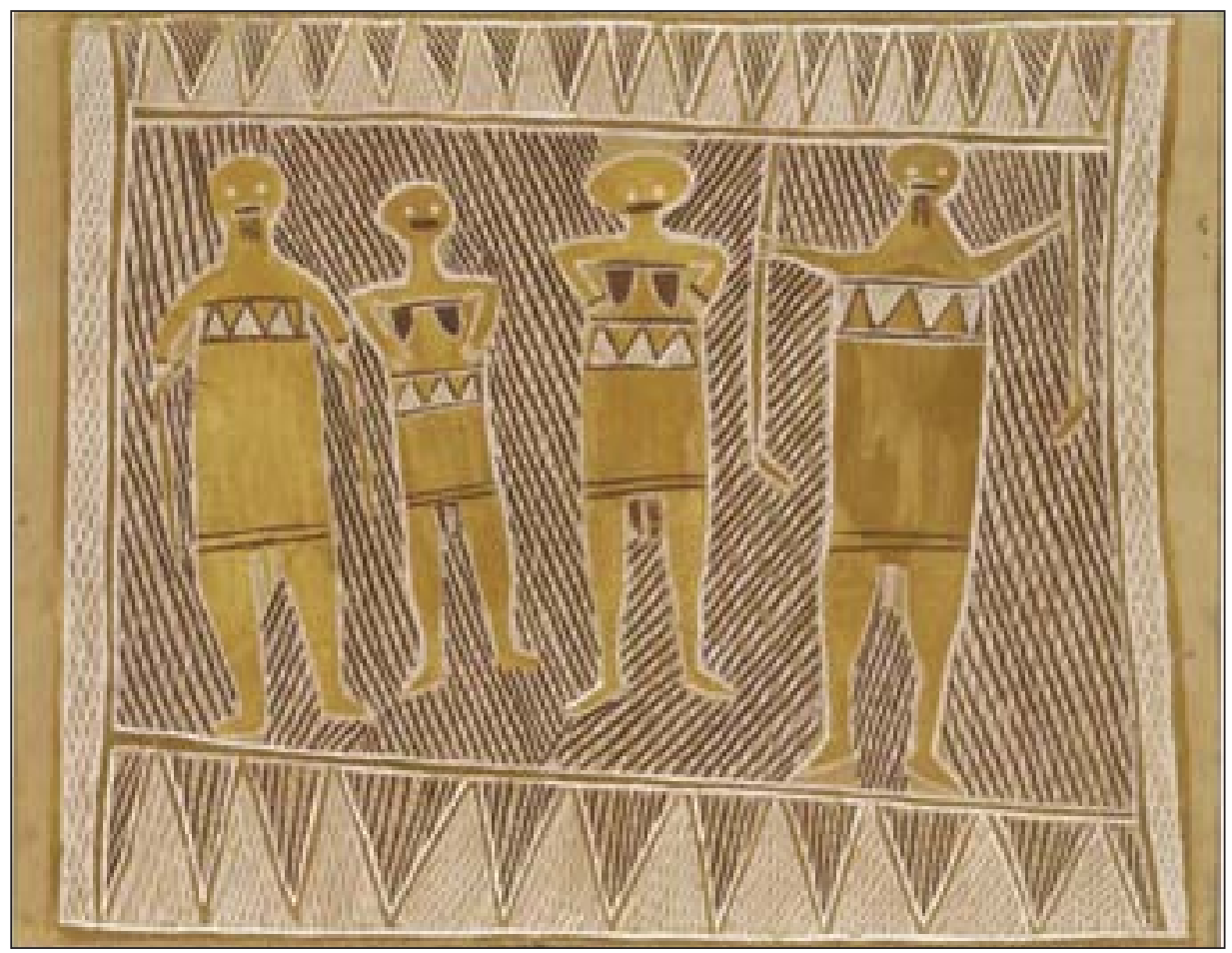

Figure 17.1 Munggurray Yunupingu, Bayini men and women of Port Bradshaw. Painting collected by Charles Mountford and donated to the Art Gallery of New South Wales by the Commonwealth of Australia in 1956. Natural pigments on paper, 45.5 x $58.5 \mathrm{~cm}, 1948$

Artist unknown. By permission of the Art Gallery of New South Wales. Accession No. 9270. C Estate of Munggurraw Yunupingu, courtesy of Buku-Larrnggay Mulka Centre. Photograph: Brenton Mcgeachie.

2 McIntosh, I. S. 1996, 'Islam and Australia's Aborigines? A perspective from north-east Arnhem Land', Journal of Religious History, vol. 20, no. 1, pp. 53-77. 


\section{The Shock of Disclosure}

If the 1948 American-Australian Scientific Expedition to Arnhem Land appears today as a mere footnote in the history of northern Australia, it is a footnote that nonetheless still packs a punch in certain Yolngu contexts. ${ }^{3}$ Perhaps the most significant legacy of the Expedition is the revolution that Ronald Berndt described in his groundbreaking monograph, An Adjustment Movement in Arnhem Land (1962). ${ }^{4}$ A radical transformation was taking place in Yolngu lives from Milingimbi to Yirrkala and it was sparked, according to my close friend and confidant, the Yolngu leader David Burrumarra, by the shock that followed the disclosure on film of certain sacred works of Yolngu art collected by Expedition members. Berndt quotes Burrumarra, one of the instigators of the 1957 movement, about the chain of causation:

They [Expedition members] took pictures of our sacred ceremonies and rayga [ceremonial objects], and we got excited. Why do they do this? We understood when Warner, Thomson and the Berndts were here. But why do they come again and again to study us? They take photographs of sacred things and show them to all the people throughout Australia and other places...We got a shock. We're not supposed to show these mareiin, these rayga to just anybody...All this made us think...Then we saw a film at the Elcho church. It was from the American-Australian Expedition, and it showed the sacred ceremonies and emblems. And everybody saw it...We've got no power to hide (these rayga): they are taking away our possessions. Are we to lose all this? Our most precious possessions - our rayga! We have nothing else: this is really our only wealth. $^{5}$

Yolngu at the Elcho Island (Galiwin'ku) mission, in particular, had been searching for a way of satisfactorily adjusting or bringing together the very best of Aboriginal and Western ways of living without compromising the integrity of their own society and culture. ${ }^{6}$ According to Burrumarra, as reported by Berndt, there was a strong sense that people were lost between two worlds, and things came to a head in the wake of the visits of the American-Australian Scientific Expedition to the Yolngu communities of Yirrkala and Milingimbi. The adjustment movement involved Yolngu taking the unprecedented step of publicly revealing their sacred objects, creating a memorial to a way of life that

3 Mountford, C. P. (ed.) 1956, Records of the American-Australian Scientific Expedition to Arnhem Land. Volume 1: Art, myth and symbolism, Melbourne University Press, Carlton, Vic.

4 Berndt, R. M. 1962, An Adjustment Movement in Arnhem Land, Mouton, Paris.

5 Ibid., (see Note vi), p. 40.

6 Burrumarra's nephew Wandjuk Marika from Yirrkala worked closely with Mountford in 1948 and was one of a number of Yolngu leaders from other Christian missions who opposed the adjustment movement and the very idea of the public revelation of sacred paraphernalia. 
was changing forever. Yolngu would now follow two laws: Aboriginal and nonAboriginal. They would be Christian in a Yolngu world and Yolngu in a Christian world, with each informing the other in an arrangement that Burrumarra would call 'membership and remembership'. While investigators such as Mountford were busily documenting a moiety and clan-based identity for Yolngu artists, a new pan-Yolngu Christian social order was being constructed by Yolngu themselves - one that was inclusive of selected non-Aborigines who were adopted into their kinship system. ${ }^{7}$

The Arnhem Land Expedition was not in itself the cause of this revolution, but the public presentation of those sacred images on film at Elcho Island certainly had an impact. Members of the Expedition, I imagine, would have viewed this as an entirely unanticipated consequence of their scholarly activity. Anthropologically speaking, they were on a 'search and rescue' operation and had no interest in the theological or cosmological ruminations of 'mission boys' such as Burrumarra or his nephew Wandjuk Marika (who provided paintings to the Expedition at Yirrkala) or the status of the Yolngu embrace of Christianity.

But team leader, Charles Mountford, did have a strong interest in the history and legacy of Yolngu contact with Macassans. These Muslim traders from the entrepot of Macassar on the island of Sulawesi in eastern Indonesia had been visiting northern Australia and interacting with Yolngu from at least 1780. They were in search of bêche-de-mer or trepang in the shallow Arafura Sea inter-tidal zone, in what is described as Australia's first international trade. ${ }^{8}$ The legacy of this extended contact was substantial. ${ }^{9}$ A considerable number of Yolngu rituals feature references to the artefacts of trade such as boats, anchors and flags, life in South-East Asian seaports, and the notion of a high god called 'Allah' (or Walitha' walitha). Pioneering anthropologist Lloyd Warner documented some of these rituals during fieldwork in North-East Arnhem Land in the late 1920s. ${ }^{10}$ By the 1940s, however, Yolngu were guarded in their responses to Mountford's questioning on such topics, especially Islam, as evidenced in the largely cryptic information on the mysterious group of Islamic traders who had supposedly preceded the Macassan trepangers. These visitors, called the Bayini, were unknown to the literature prior to the 1940s.

\footnotetext{
7 McIntosh, I. S. 2000, Aboriginal Reconciliation and the Dreaming, Warramiri Yolngu and the Quest for Equality, Cultural Survival Series on Ethnicity and Change, Allyn and Bacon, Boston.

8 Macknight, C. C. 1976, The Voyage to Marege': Macassan trepangers in northern Australia, Melbourne University Press, Carlton, Vic.

9 Macknight, C. C. 2008, 'Harvesting the memory: open beaches in Makassar and Arnhem Land', in P. Veth, P. Sutton and M. Neale (eds), Strangers on the Shore: Early coastal contacts in Australia, National Museum of Australia, Canberra, p. 137; McIntosh, I. S. 2008, ‘Pre-Macassans at Dholtji?: exploring one of north-east Arnhem Land's great conundrums', in Veth et al., Strangers on the Shore, pp. 165-80.

10 Warner, W. L. 1958, A Black Civilization: A social study of an Australian tribe, Harper and Row, New York.
} 
There was a fundamental difference in the stories of these pre-Macassans or Bayini and the Macassan trepangers. The former had a sacred or 'hidden' dimension that spoke to the very essence of what it meant to be Yolngu in the world that now included others. The latter belonged to a profane dimension. These were the stories of a long history of trade and interaction of both a positive and a negative nature.

The concealment of the stories of the Bayini beyond fleeting references to them building boats, making pottery, growing rice, or weaving on their looms was quite thorough. But then there are those even more obscure references to Bayini 'flying fox' people creating sacred waterholes, or the story of the birth of the first light-skinned baby - obviously the result of a liaison between a Yolngu woman and an Indonesian man. These stories speak to an entirely different level of significance.

In the 1940s, it was not a simple matter of the Yolngu strategically forgetting anachronistic traditions or those in conflict with Christianity (or Islam) in order to facilitate the growth of the Christian mission, though this was certainly encouraged, as I have said elsewhere. ${ }^{11}$ The sacred narratives of the Bayinidescribed by Burrumarra as his 'backbone' - speak to Yolngu feelings of selfworth and dignity at a time when their material poverty was most pronounced and when missionaries promoted guilt and shame as tools for Christian conversion. In the terminology of the American anthropologist and subaltern studies specialist James C. Scott, a 'hidden transcript' was concealed from the prying eyes of anthropologists and others determined to unlock every secret that Yolngu possessed, including - especially - those secrets that spoke of the increasingly problematic place of uninvited whites in a Yolngu world. ${ }^{12}$

Scott argued that all subaltern or subordinate peoples resist domination in similar ways, never consenting to their dominance. He uses the term 'public transcript' to describe interactions between the oppressor and the oppressed and 'hidden transcript' for the critique of power that goes on offstage and out of sight of power holders. In this chapter, rather than uncovering what must remain hidden, I review what lies beneath the surface of those public interactionssuch as when Mountford and his team were in search of ethnographic minutiae, in which the oppressed appear to accept their domination and happily oblige the whims of the oppressor.

I spent a number of years in Arnhem Land living and working in close cooperation with Berndt's informant the late David Burrumarra MBE of Elcho Island (1917-94), and we spoke in considerable detail about the Yolngu response to the Expedition presence, the associated films, and the adjustment

11 McIntosh, Aboriginal Reconciliation and the Dreaming, Warramiri Yolngu and the Quest for Equality.

12 Scott, J. C. 1990, Domination and the Arts of Resistance. Hidden transcripts, Yale University Press, New Haven, Conn. 
movement it helped to engender. While I was not privy to the details of the 'hidden transcript', Burrumarra was convinced that I understood its nature and purpose. It was at the very heart of our extended conversations on the history of black-white relations in Arnhem Land and indeed Australia.

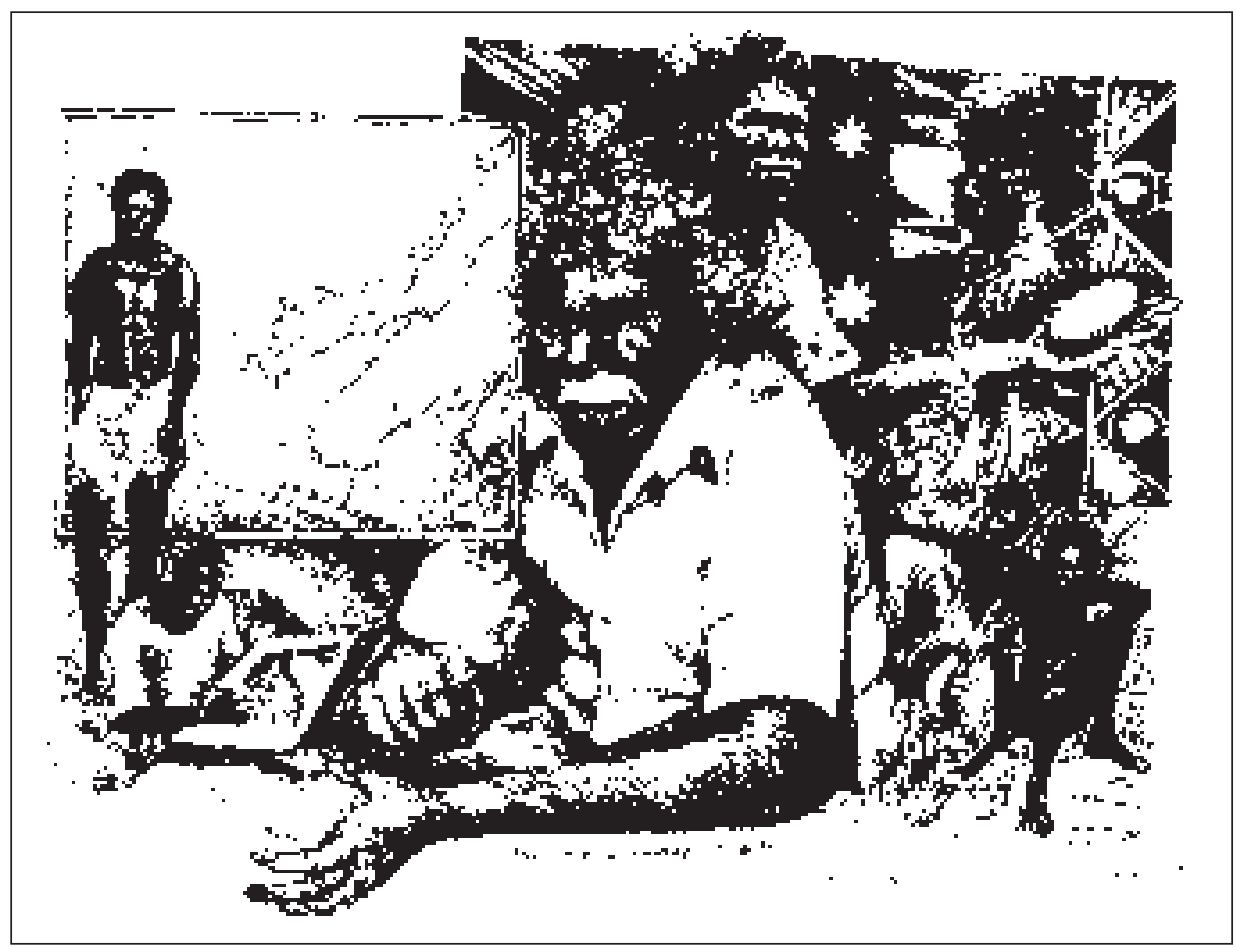

Figure 17.2 David Burrumarra of Elcho Island, 2009

Drawing by Julia Blackburn

A short anecdote brings his reasoning to light. On one occasion, Burrumarra and I were witnessing the final stage of the Kunapipi ritual - that stage when the initiates present themselves to the community after a protracted absence journeying 'inside the belly of the snake' to reassure family members that they are still in the land of the living. It was dawn and we were both painted with red ochre - symbolic of the menstrual blood of the ancestral sisters 'swallowed' by the rainbow serpent. I recall asking Burrumarra various questions about the antiquity of the ritual - it looked so foreign and ancient - and he was disappointed that I would talk in such terms. This ritual was not about the past, he said. Didn't I have the red paint on me? The serpent was not separate from the collected peoples assembled on that cleared sandy performance space. I was a part of this ritual. It was not just the dancers. There was no category of outside observer! 
In the same way, Burrumarra showed great interest in my attempts to decipher the deeper significance of the Bayini narratives. Volume after volume of field notes that I collected during our conversations (and later as part of my doctoral studies in anthropology) on every aspect of this legacy in song, dance, sites, personal names, totemic emblems, artefacts, and occupations, represent merely an outer layer, Burrumarra said. If I really wanted to comprehend the Bayini, Burrumarra added, 'Look at the way I act'. His lifelong battles to secure a better life for Yolngu, the endless fight in support of sea and land rights, are all central to an understanding of the Bayini. ${ }^{13}$ The meaning of the stories and of the 'hidden transcript' was embodied in the very nature of these daily unequal public transactions between Yolngu and outsiders.

\section{The History of Disclosure}

Towards the end of his life, Burrumarra revealed much about the way in which Bayini narratives were withheld, not only from anthropologists and historians but also from younger members of the Yolngu community. ${ }^{14}$ On a number of occasions, he told me that the narratives were too sacred, too complex and for many years had helped to define the nature of cross-cultural interaction. A clean break from the past was required in the interests of building new, strong and vibrant Christian communities. ${ }^{15}$

But Burrumarra also revealed deeper reasons for nondisclosure: the power imbalance between black and white Australians, which is a central theme in the Bayini narratives. ${ }^{16}$ As far back as the 1920s, Burrumarra's close relative Harry Makarrwola, who was the chief informant for Lloyd Warner, was struggling with what to disclose on this topic. While there is no mention of pre-Macassans or Bayini in Warner's published account, ${ }^{17}$ there is a strong suggestion from his data that there existed in Yolngu discourse some overarching belief associated with the power and prestige of the Other - a power that rightfully belonged to the Yolngu. Specifically, the notion of a 'Dreaming Macassan' appears to provide the nucleus for Yolngu thoughts on the origin and purpose of nonAborigines - in particular, Macassan trepangers and then, later, Japanese and Europeans. This Dreaming entity (which encapsulates all the Bayini narratives) is known as Birrinydji and narratives associated with him provide Yolngu with

\footnotetext{
13 McIntosh, 'Pre-Macassans at Dholtji?'.

14 McIntosh, I. S. 1994, The Whale and the Cross: Conversations with David Burrumarra MBE, Northern Territory Historical Society, Darwin.

15 And yet, those rituals associated with the Bayini would continue to be performed on a regular basis across the region, especially during funerals. McIntosh, I. S. 2004, 'Personal names and the negotiation of change: reconsidering Arnhem Land's adjustment movement', Anthropological Forum, vol. 14, no. 2, pp. 141-62. 16 McIntosh, Aboriginal Reconciliation and the Dreaming, Warramiri Yolngu and the Quest for Equality.

17 Warner, A Black Civilization.
} 
an understanding of who these outsiders were and why they were on Yolngu land, and also answer key questions about their own place in the world. For example, why did Yolngu work for the Macassans, and not the other way around? What must have gone wrong at the beginning of time for the influence of these outsiders to be so pervasive?

In the 1940s and 1950s, however, researchers Charles Mountford and Ronald and Catherine Berndt would make no reference to the existence of the deity known as Birrinydji. ${ }^{18}$ A significant change was taking place in the nature of Yolngu accounts, a shift in emphasis from a mythical perspective with respect to outside visitation to a focus on the perceived historical nature of both preMacassans (or the Bayini) and Macassans. The concept of the 'Bayini' was born at this point - the choice of words indicative of the presence of a 'hidden transcript'. Bayini is a word that means woman-a golden-skinned woman married to Birrinydji, the Dreaming Macassan. As Burrumarra once said to me, in his conversations with Balanda, he and his peers would emphasise the exploits of Bayini women, revealing only those accounts that were suitable for Yolngu women and anthropologists to hear. The exploits of Birrinydji and Bayini men were not historical in nature and therefore not negotiable in the mission environment.

Right up to the late 1980s, nothing substantial was added to the scholarship on the Bayini, despite the investigations of a considerable number of anthropologists. The Macassan trepanging past had been definitively recorded by historian Campbell Macknight, and, for many, his book The Voyage to Marege' (1976) brought closure to this avenue of inquiry, despite its lack of deeper investigation into Yolngu perspectives on the Macassan past. The Bayini, in Macknight's classic work, are dismissed simply as a reflection of Aboriginal experiences in South-East Asia, transposed onto Arnhem Land shores. Macknight says: 'The idea of things which properly belong overseas has been transferred to familiar places in order to integrate this knowledge into the spatially oriented framework of Aboriginal thought. ${ }^{19}$ Importantly, however, he also says that the Bayini stories are a 'most remarkable instance of the need to distinguish between the account of the past current in a society and the actual events of the past ${ }^{\prime}{ }^{20}$ Yes, but with little or no access to data on the pan-Yolngu significance of the Bayini, it was impossible for Macknight to reach a more substantial conclusion as to their significance. Even by his own admission, Macknight's field references to the Bayini (following his visits to some of the most important Bayini-and Birrinydji-sites along the

18 Berndt, R. M. and Berndt C. H. 1954, Arnhem Land: Its history and its people, F. W. Cheshire, Melbourne.

19 Macknight, The Voyage to Marege', p. 92.

20 Ibid., p. 161. 
coast) are obscure to the point of incomprehensibility. Burrumarra, for example, told Macknight (in the wake of the Apollo moon landing) that the Bayini came from the moon!

The very noticeable absence of anthropological references to the Bayini post Mountford is curious because even today the principal distinguishing feature of North-East Arnhem Land communities is the presence of artefacts connected with the Dreaming Macassan - most noticeably the ubiquitous flagpole and flag, and the mast complete with rigging stationed in the centre of communities all of which signal the presence of Birrinydji and his 'replacements', a people whom Yolngu in the 1940s called, in their own cryptic fashion, the Bayini. As I have described previously, the Bayini are understood to have sung certain Yolngu lands into existence and then lain down on the sand to rest. ${ }^{21}$ While Birrinydji is associated most closely with a number of clans including the Warramiri, Lamamirri and Dhalwangu, all Yolngu in North-East Arnhem Land are understood to claim descent from the Bayini either through their mothers or fathers.

\section{Comparing Transactions}

When artworks (and their associated commentaries) were presented to Mountford and other Expedition members in 1948, the Yolngu had no idea what would become of them. Trust was implied as the transaction was being conducted in a controlled setting: a Christian mission. But there was little or no consideration given to how Yolngu might feel about the reproduction of their works in books or on film and there was certainly a lack of sensitivity towards issues of ownership regarding items of cultural significance (see also Garde, this volume). Expedition anthropologists were a long way, for example, from the ideal of 'stranger and friend' championed by Hortense Powdermaker. ${ }^{22}$ The concept of participant observation played little part in the Expedition's methodology. Just a year after the Mountford Expedition, Ronald and Catherine Berndt's collection of sacred Bayini sculptures was displayed in Sydney's David Jones department store to a bemused shopping public. ${ }^{23}$

According to the Art Gallery of New South Wales Curator, Jonathan Jones, Mountford's approach to collecting artwork and the related narratives was unorthodox. Mountford said of his method: '[I would] ask the men to make bark

21 McIntosh, 'Pre-Macassans at Dholtji?'.

22 Powdermaker, H. 1966, Stranger and Friend: The way of an anthropologist, W. W. Norton \& Co., New York.

23 Gray, G. 2009, 'Cluttering up the department: Ronald Berndt and the distribution of the University of Sydney ethnographic collection', Recollections: Journal of the National Museum of Australia, vol. 2, no. 2. 
paintings for me, seldom suggesting a subject. At the end of each day, the artists bought [sic] their work to my tent, related the associated myth, and explained the meanings of the designs. ${ }^{24}$

Team member Frederick D. McCarthy, as reported in Jones, was openly critical of this approach, recalling how at

dusk or thereabouts he [Mountford] got [the Aboriginal artists] together near his tent... and hammered the interpretation out of them, sometimes in a friendly way, at others [in a] bullying style...His data is [sic] not the product of spontaneous work on the part of the native but has been got from a short-term 'pounding' of the informants. ${ }^{25}$

We know that the Yolngu artists were paid for their work with tobacco, food and sometimes coins, in transactions reminiscent of those of missionaries, when the amount of sustenance granted or withheld was based on how dutifully the Yolngu had completed their assigned tasks that week. ${ }^{26}$

Given the material poverty of mission residents, cooperating with Mountford was undoubtedly an attractive idea. And while disclosure of certain Dreamingrelated themes by Yolngu was thorough, Mountford's bullying on the subject of the Bayini resulted in a curious collection of images and an enigmatic text - a perplexing picture of the past that has inspired wild speculation on the part of scholars who would follow. Some would argue, for example, that the Bayini were Portuguese while others believed them to be members of Zheng He's voyage of discovery - suggestions that have no merit.

In the 1940s, Yolngu were willing to freely share images of the Bayini and Macassans with non-Aborigines but what was being released by Yolngu in the form of narratives was very restricted and a product of considerable community discussion and negotiation.

If we compare the Mountford transactions with similar ones occurring 40 years later in North-East Arnhem Land, the role of the community in determining the extent of disclosure and concealment is readily apparent.

In the mid-1980s, Yolngu on Elcho Island would welcome the visits of Ramangining art advisor and scholar Djon Mundine. With chequebook in hand, he would stand on top of the council office stairs in company with various Yolngu elders (and in front of a considerable crowd) as various art objects were presented to him for sale. In consultation with those gathered, he would make his decisions on whether to purchase the item and what level of compensation

24 Jones, J. n.d., Mountford Gifts: Work from the American-Australian Scientific Expedition to Arnhem Land 1948, Art Gallery of New South Wales, Sydney.

25 Ibid.

26 McIntosh, The Whale and the Cross. 
would be offered. Were the pandanus mats and dilly bags of sufficient quality? Was the artwork suitable for public release and distribution? Every so often a sacred painting would be presented for sale and the decision to proceed (or not) was often in the hands of certain selected members of the assembled body of Yolngu.

Very occasionally a painting would appear that was inappropriate for general viewing or sale, and, on more than one occasion, on the orders of elders such as Burrumarra, it was buried in the sand at some undisclosed location or sent to the waterhole's murky depths - the artist publicly shamed.

One can only imagine, then, the sorts of discussions that were taking place in the camps at Yirrkala and Milingimbi during the visits of Expedition members in the 1940s. What could be shared with outsiders, and what would remain untold, and why? What new interpretations of old stories were required in order to negotiate the changing nature of their world in ways that promoted their interests as Yolngu?

\section{The Context of Disclosure}

One example of the challenge of disclosure for Yolngu was made evident by Burrumarra in the late 1980s when he was describing, in elaborate detail, the nature of the 'public transcript' (as opposed to the 'hidden transcript'). In the public transcript, the Macassans might have developed close relationships with Yolngu but they were still the Other. In these stories, we can still see the proof of this past, the physical traces of the once prominent Macassan trepang industry: tamarind trees, stone lines and broken pieces of pottery lining the shores of North-East Arnhem Land. In the 'hidden transcript', in contrast, the Bayini are not the Other. They are Yolngu but with a language that comes from a place far away to the north of Australia. In these stories there is no trepang because the Bayini were not trepangers. They were the bringers of the law to the Yolngu, the law that described the injustice that Yolngu felt at the hands of the Europeans and the Macassans who came before them.

According to Burrumarra, the public transcript also sends a very powerful message about the history of cross-cultural encounters. He described to me various waves of foreign visitation to Arnhem Land, emphasising the changing skin colour of groups over the vast passage of time. The earliest visitors were black and they lived as Yolngu, respecting Yolngu laws. Reciprocity was a feature of their relationship. These visitors were the ones, for example, who cared for the souls of the Yirritja moiety dead in a paradise believed to exist somewhere to the northeast of Arnhem Land in a place called Badu or Nalkuma - the subject referred to in many images and explanatory notes in Mountford's Expedition report. 
Next in this historical narrative came the gold-coloured Bayini, who introduced new laws and technology to the Yolngu. Their impact was both profound and problematic. According to Burrumarra, they were deficient in passing on their advanced skills to Yolngu, leading to all manner of chaos and despair. ${ }^{27}$

Finally there were Macassan trepangers, Japanese pearlers and then Europeans. The visitors in each new wave were ever lighter in skin colour-an expression of the lessening interest in reciprocity and respect in their dealings with Yolngu.

The important thing to remember, said Burrumarra, was that Birrinydji (the Dreaming Macassan) had drawn forth all of these seafarers-black and white and everything in between - onto the Arnhem Land coast by the strength of his marr or desire for the Yolngu and their future. This entity introduced Yolngu, in varying stages, to a new world of material riches and opportunity, but also, ultimately, to the inequality and dispossession that Yolngu were experiencing in their daily lives.

The old adage 'speaking truth to power', or standing up for your rights in a very unequal battle, Scott says, always has a utopian ring to it because it is so rarely practised..$^{28}$ How could the Yolngu even share this story with the Mountford Expedition or others? Like the hidden transcript, it was essentially a critique of the failure of those non-Aborigines who held dominion over Yolngu lives to value their history, laws or traditions. So what we therefore find in the Expedition report is a very detailed account in bark and narrative of the first wave of visitation of those people who ultimately care for the Yolngu in the 'land of the dead', but very scant information on all the other waves of visitors, such as the Bayini and Macassans.

\section{The Christian Dimension}

One of the most significant constraints on disclosure by Yolngu in Mountford's day was whether or not the narratives to be shared with Expedition anthropologists were consistent with, or had been superseded by (or absorbed into), Christian teachings. Mountford's report, as mentioned, reveals a very significant amount of information on the notion of a Yolngu 'land of the dead', so this topic was obviously unproblematic in terms of Yolngu disclosure. Biblical narratives took precedence in describing the nature of the soul's journey to this paradise. Public revelation of such details could only help to ensure the consignment of this Yolngu belief to the past. Burrumarra, for example, would openly speak of how sceptical he had been, even as a youth, about the stories he had heard from his

27 McIntosh, 'Islam and Australia's Aborigines?'.

28 Scott, Domination and the Arts of Resistance, p. 1. 
older brother of a whale carrying the soul of the dead on its back to an unknown place called Badu. He was intrigued by these stories, but acknowledged that they had little bearing on his life or the lives of other mission Yolngu. More important to him was the belief that the final resting place of the soul was the sacred waterholes located on his homeland at Dholtji and Gulirra in places that he often described as paradise or heaven.

The partial and confused stories of the Bayini that were told to Mountford, however, were not so easily consigned to the past. One can see in hindsight that the jumbled mix of myth and history was sending forth a strong message that they were, at the very least, in conflict with the Christian message.

The 1940s and 1950s were a time when the foundational Dreaming deities for the two Yolngu moieties (Dhuwa and Yirritja) were being recast as Old Testament prophets - a process that was sped up following the adjustment movement. The significance of the God-figure 'Allah' that Yolngu had learned about through hundreds of years of interaction with Indonesians was also being reconsidered and reconfigured. As I have written elsewhere, mission elder Harry Makarrwola in the 1950s spoke of Allah in the new scheme of 'adjustment' thinking as a messenger of the God of Christians. ${ }^{29}$ Even on Elcho Island today, funerary rites that invoke the will of Allah are still enacted, but they are inevitably followed by Christian prayers and hymns - evidence of the continued existence of a hidden transcript.

This transition in interpretations of the Bayini was a subject of serious debate in the 1940s right across North-East Arnhem Land missions, but it was not a mere reflection of the will of Christian missionaries. The Elcho Island Church, for example, is built on a sacred site associated with the totemic eagle's nest. The decision to locate it there was made by missionaries and Yolngu alike. Within the walls of the church were placed special rocks associated with the moiety deities, so the message was very clear: while Yolngu were now part of the greater Christian body, the law of the land was integral to their understanding of the new ways. As if in confirmation of this 'eternal truth', it is said that one of the stone 'bilma' or clap-stick rangga placed in the church wall replicated itself in the landscape of its own volition. As it was removed from the ground by Yolngu Christians another moved upwards to replace it. This was a powerful statement for Yolngu of Burrumarra's concept of 'membership and remembership' - the notion that the new was grounded in the old, and that the old could never vanish entirely from the world. 


\section{A Startling Disclosure}

The most startling disclosure regarding Birrinydji (and the Bayini) came in 1988 at the hands of Burrumarra when he revealed for the first time an image of this deity. ${ }^{30}$ This painting was not created for sale, but rather as an extension of the adjustment movement 'revolution'. Burrumarra wanted a new flag (or series of flags) for Australia in which the most significant Dreaming elements of the land on which the flag was being flown would be represented alongside non-Aboriginal symbols such as the Union Jack - all in the spirit of Aboriginal reconciliation. For his clan, the Warramiri, the most significant symbols were the octopus, the whale, and the Dreaming Macassan-Birrinydji.

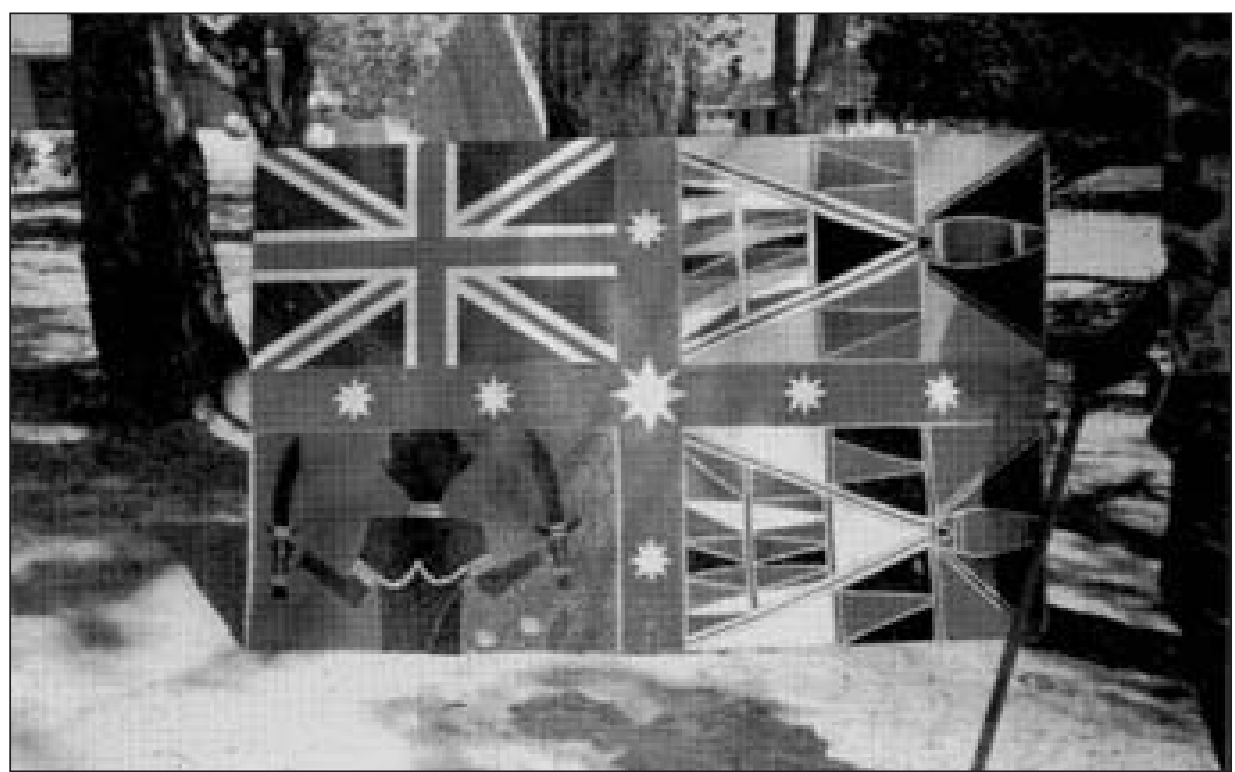

Figure 17.3 Flag treaty proposal featuring an image of Birrinydji, the Dreaming Macassan, painted by George Liwukang and David Burrumarra. Oil on masonite, 1988

By permission of the Faculty of Law, University of New South Wales.

In Burrumarra's view, Yolngu were still relying too much on the hidden transcript in the wake of the adjustment movement. Apart from the Birrinydji and Bayini narratives, all other major beliefs had been fully disclosed and documented at great length by anthropologists in numerous theses and texts. With this body of law becoming increasingly anachronistic in the growing Christian community, the time for the Dreaming Macassan's disclosure had arrived, according to Burrumarra. His rationale was simple. He wanted to remind his fellow Yolngu that white wealth came from Aboriginal land, and that indigenous Christianity had a long history, based as it was on a foundation that included hundreds of

30 McIntosh, Aboriginal Reconciliation and the Dreaming, Warramiri Yolngu and the Quest for Equality. 
years of contact with Islam. Christianity was not the white man's religion at all. It was a Yolngu religion, for the Yolngu were Birrinydji's people, and the followers of Birrinydji were Christian.

But Burrumarra's desire for disclosure was met with considerable opposition. Many wanted this Dreaming to remain concealed from white eyes. For Burrumarra, Christianity was an expression of the will of the Dreaming Macassan. For others, however, it was also of continuing relevance in shaping private discourse (and negotiating relations) between black and white. Birrinydji and Bayini narratives were therefore not subjects that should be freely shared in the public domain. But Burrumarra persisted with his decision, and, as the senior spokesperson for this Dreaming law, he would not be dissuaded.

Very soon after this momentous interaction, and with Burrumarra's permission, the Dhalwangu clan produced an image of Birrinydji on a signboard at their outstation at Gurrumurru, to the south-east of Elcho Island on Arnhem Bay. As if overnight, entirely new interpretations of the Birrinydji and Bayini legacy began to emerge. ${ }^{31}$

In Burrumarra's narrative (also reflected in the account given by Makarrwola to Warner in the 1920s), Yolngu at one time believed themselves to have been white, rich and all powerful. But, as I have described in detail elsewhere, when the Dreaming Macassan, Birrinydji, left Arnhem Land after his creational exploits at the 'beginning of time', Yolngu were set on a course to become black, poor and subject to domination. ${ }^{32}$ In the newly emerging Dhalwangu account, however, Birrinydji never left Arnhem Land, and the Bayini have been reinstated as a pre-Macassan presence whose real purpose is not, and perhaps never will be, open to the prying eyes of the Other. In the stories that have been shared, the Bayini are seafarers who, at the dawn of time, make their way from points south of Numbulwar in the Gulf of Carpentaria, around Dholtji and Cape Wilberforce, and into Arnhem Bay and Gurrumurru, where their journey ends as mysteriously as it began.

\section{Reflections on Disclosure}

When considering the legacy of the 1948 Arnhem Land Expedition, it is not enough to simply reflect on lost opportunities. A longer-term view of disclosure regarding the Bayini sheds light on the ways in which Yolngu were transforming their own worlds in unique ways - under the guidance of missionaries to be

31 Toner, P. 2000, 'Ideology, influence and innovation: the impact of Macassan contact on Yolngu music', Perfect Beat, vol. 5, no. 1, pp. 22-41.

32 McIntosh, Aboriginal Reconciliation and the Dreaming, Warramiri Yolngu and the Quest for Equality. 
sure, but in ways that reflected their own specific interests and concerns. The Expedition's salvage focus made it blind to these transitions, but their presence, in hindsight, actually played into the hands of people such as Burrumarra who had an integrationist mind-set.

So complete today is the apparent transition from a mythological to a historical perspective with regards to the pre-Macassan past that the significance of the former hidden transcript seems to be lost in time. But such a conclusion is problematic at best, given the rapid reworking of the Dreaming Macassan legacy following the disclosure by Burrumarra in the late 1980s.

Mountford's bullying could in no way elicit such a nuanced reading of the Yolngu past. To share exhaustive information on the Bayini in 1948 would have been difficult at best, and undoubtedly also compromising for Yolngu. As Burrumarra detailed in discussions described by Berndt in An Adjustment Movement in Arnhem Land, the Yolngu were seeking to extract the very best from the non-Aboriginal world in order to strengthen their own society. In a political environment in which there was an enormous disparity in power between whites and blacks on Aboriginal land, to suggest to outsiders that they might actually hold some privileged place in Yolngu cosmology (because the Bayini were themselves white or golden coloured), would have been seen as counterproductive.

Beliefs associated with the Bayini are fluid, not static. Both the public and the hidden 'transcripts' exhibit considerable complexity. The challenge for Expedition anthropologists to salvage ethnographic data regarding preMacassans was very considerable. But in order to find answers to their questions, they should have also looked to the future, not just the past. If they had taken Yolngu Christianity seriously and not prioritised the search for the primitive, the dynamism of Yolngu religion, and the multifaceted role it plays in Yolngu lives in the intercultural arena, would surely have been showcased. In their search for a romantic past, they missed the revolution taking place before their eyes.

Mountford's interest in the sorts of debates circulating in Yolngu communities at the time was negligible. His ethnographic team had the ambition of bringing to light every possible detail of the past. But, as I have described, this was not going to happen. Arnhem Land was in a state of flux and there were major debates unfolding about Christianity and the Dreaming. Was God a product of the Dreaming, as many Yolngu elders believed, or did God give Yolngu the Dreaming? It was a pity that Expedition members were so little interested in this debate because they might have learned something of the inside view of the Bayini. They would have surely seen how actively the Yolngu were participating in making their vision of the future coincide with an idyllic image of the past 
embedded in the Bayini narratives - stories of black and white people living and working together in peace and harmony, sharing equally in the resources of the land and sea. That story is yet to be shared openly because the hidden transcript remains hidden, and it will remain so while injustice continues to be a feature of Yolngu lives in a Balanda world, and while the great disparity in wealth between white and black remains the defining feature of their relationship. 